\title{
A CASE OF GALACTOSAEMIA WITH THE PATHOLOGICAL AND NEUROPATHOLOGICAL FINDINGS
}

\author{
BY \\ L. CROME* \\ From the Department of Neuropathology, The Fountain Hospital, London
}

(RECEIVED FOR PUBLICATION JANUARY 24, 1962)

The following report includes hitherto undescribed neuropathological findings in a case of galactosaemia. The full clinical and laboratory data of investigations carried out during the earlier part of the patient's illness have been published already by Clay and Potter (1955) and Cusworth, Dent and Flynn (1955) and will be outlined only briefly.

\section{Case Report}

The patient was illegitimate, the putative father's medical history being unknown. The mother's intelligence is thought to be below average, although she is able to earn her own living. One older half-brother, by a different father, died from an unknown cause at 10 years. The mother's blood group is A, Rh positive, and her Wassermann reaction is negative. Vomiting was frequent during pregnancy, but the confinement was normal.

The baby weighed 3,180 g. At 9 days he became lethargic and passed some fresh blood per rectum. The following day the liver and spleen were palpable and he vomited after each feed. Jaundice set in, with a bilirubin level of $26 \mathrm{mg} . / 100 \mathrm{ml}$. The thymol turbidity was 4 units and the urine reduced Benedict's solution to brick red colour. The glucose tolerance test was normal, the curve rising to $165 \mathrm{mg}$. $/ 100 \mathrm{ml}$. At 4 weeks, small central opacities were noticed in the lenses of both eyes. Oral galactose exacerbated the vomiting at once. Galactosaemia was thus diagnosed, and the patient was thereafter maintained on a lactose-free diet. 'Casilan' served as a basis for this diet, and small quantities of butter fat were also added. The reducing substance in the urine disappeared in a day or two, the liver returned to normal size and the infant gained weight slowly but steadily.

At 2 months he developed chicken-pox and at 3 months he had intermittent muscular twitching lasting two to three weeks, which never recurred. He continued to gain weight: $4,082 \mathrm{~g}$. at $4 \frac{1}{2}$ months and $5,540 \mathrm{~g}$. at 7 months. The lenses cleared and remained so. The head circumference measured $41 \mathrm{~cm}$. at 7 months, the average normal for the age being about $44.5 \mathrm{~cm}$. with * Part of the work was done with the aid of a grant from the
Mental Health Research Fund.
S.D. $\pm \mathbf{1} \cdot \mathbf{0}$. He was thus mildly microcephalic. A liver biopsy examined at 21 months showed no abnormality. Mental backwardness now became obvious. At 2 years he was transferred to University College Hospital, London, for fuller metabolic investigations.

His blood urea was $42 \mathrm{mg}$. $/ 100 \mathrm{ml}$. with clearance of 59 and $69 \%$ corrected for body size. The urinary amino acid excretion was normal, and the urine contained no reducing substance. The blood aminonitrogen was $3.3 \mathrm{mg} . / 100 \mathrm{ml}$., and the amino-nitrogen clearance was 0.75 and $0.6 \mathrm{ml}$. per minute. A galactose tolerance test gave the following results (Table 1):

TABLE 1

\begin{tabular}{|c|c|c|c|c|}
\hline & 0 Hour & $\frac{1}{2}$ Hour & $1 \frac{1}{2}$ Hours & $3 \frac{1}{2}$ Hours \\
\hline $\begin{array}{l}\text { Glucose (mg./100 ml.) } \\
\text { Galactose (mg./100 ml.) } \\
\text { Inorganic phosphorus } \\
\text { (mg./100 ml.) } . .\end{array}$ & $\begin{array}{l}86 \\
0 \\
5 \cdot 8\end{array}$ & $\begin{array}{l}68 \\
6 \\
5 \cdot 1\end{array}$ & $\begin{array}{r}61 \\
187 \\
4 \cdot 1\end{array}$ & $\begin{array}{r}53 \\
237 \\
4 \cdot 3\end{array}$ \\
\hline
\end{tabular}

The day after the above test, $20 \mathrm{~g}$. of galactose were added to the daily diet for 15 days, whereupon large quantities of galactose were excreted in the urine until the day after the supplement was stopped. Chromatograms of the urine showed a slight increase in amino acid for some six weeks after stopping the supplement. Plasma amino-nitrogen measured $4.3 \mathrm{mg}$. $/ 100 \mathrm{ml}$. on the eleventh day and $5.5 \mathrm{mg} . / 100 \mathrm{ml}$. on the fifteenth day after the commencement of the supplement.

On the eleventh day of the galactose administration, flocculation tests were weakly positive, and serum electrophoresis showed a slight increase of $\gamma$-globulin. The blood urea rose slightly during this period to a level of $51 \mathrm{mg} . / 100 \mathrm{ml}$. Urea clearances were carried out simultaneously with the amino-nitrogen clearances. They varied slightly from time to time but were all within normal limits.

The child's weight was maintained, but his general condition deteriorated with the galactose supplement. He became more fretful and difficult to feed. Bouts of vomiting occurred after the tenth day, and the liver enlarged slightly. However, within a few days of ceasing to administer the supplement, the appetite and general activity improved and the liver appeared to diminish in size. 


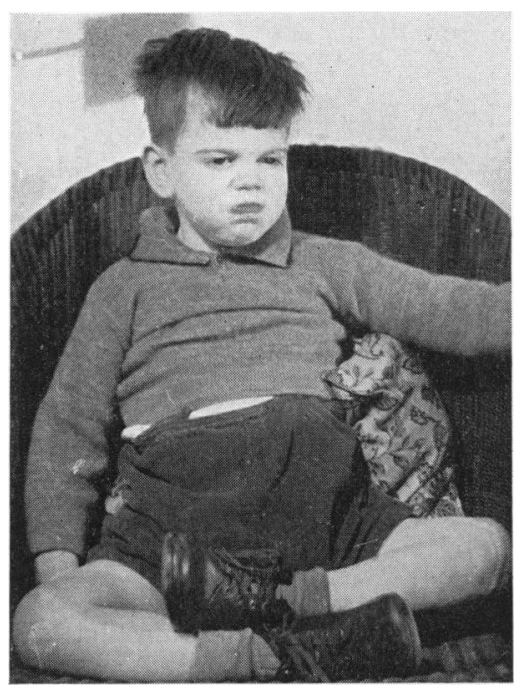

FIG. 1.-The patient aged 5 years.

As a result of these studies, it was concluded that the child was quite intolerant to the amount of galactose present in a one-litre daily ration of milk. The associated amino-aciduria was thought to be mainly renal and not due to a rise in the level of blood amino acids, although there was a slight but definite rise in blood amino acids during this period, presumably due to liver damage.

Owing to unsatisfactory home conditions, he spent his whole life in hospitals. At 5 years he was admitted to the Fountain Hospital, where he remained till death.

On admission (Fig. 1) he was found to be somewhat stunted, weighing $15 \mathrm{~kg}$. and measuring $88.9 \mathrm{~cm}$. in height. The head circumference was $48.3 \mathrm{~cm}$., the average normal for the age being $51 \cdot 3 \mathrm{~cm}$. with S.D. $\pm 1 \cdot 2$. He had a hairy face and trunk, a large mouth and a somewhat asymmetrical skull. His facies were faintly suggestive of gargoylism, but radiographs of the skull and spine showed no evidence of this condition. $\mathrm{His}$ ocular media were clear. The tendon jerks were present and equal, the knee jerks being particularly brisk. Plantar responses were flexor.

The mental retardation was general, but he was more backward in speech and hearing than in locomotor functions. He could hear, but the responses to sound were negativistic: he turned away from it or held his hand to his ear. He seemed to be more attracted by objects than persons. He tended to resist being taken on one's lap and showed some withdrawal. His assessment on the Vineland Social Maturity Scale was: Social age (S.A.)-19-20 months, and social quotient (S.Q.)-33. Mental age on the Griffith's developmental scale was 54 weeks and the general quotient-21.

In the ensuing year he learned to walk with a somewhat odd and stiff gait. He played a little with bricks and tins, rolling and dropping them. He still had no speech or verbal comprehension, but smiled a little when he was played with. His assessment at 6 years was: S.A.1 year, and S.Q.-16, on the Vineland Social Maturity Scale. There was thus an apparent drop in intelligence relative to age from the time of admission, and he was considered to be somewhere on the borderline of idiocy and imbecility.

During the following two years his condition remained essentially unchanged. He was maintained on a mixed, milk-free diet but often attempted to snatch milky foods from other patients, any substantial ingestion of milk being followed by bouts of vomiting. He contracted and recovered satisfactorily from a number of incidental illnesses such as enteritis and respiratory and skin infections. From time to time he became very anaemic and this was treated with 'Imferon'. His walking gradually improved and he could also run and play with a ball. He learned to feed himself with bread and butter but could never master a spoon; he remained speechless and doubly incontinent.

He died at 8 years from bronchopneumonia and otitis media.

Pathological Findings. The whole brain weighed $1,052 \mathrm{~g}$., and the cerebellum with the brain-stem $125 \mathrm{~g}$. (The average total normal weight for the age is $1,273 \mathrm{~g}$.) The meninges over the vertex of the brain were slightly opaque and the Pacchionian corpuscles unduly prominent. The pattern of convolutions was normal but the gyri were somewhat narrow and the sulci between them correspondingly wide. The optic nerves measured $4.0 \times 2.5 \mathrm{~mm}$. and the cut surface of the optic nerve was $3 \mathrm{~mm} .{ }^{2}$ below the average for the age, but probably still within normal limits. All other cranial nerves and the main blood vessels at the base of the brain were normal.

The brain was fixed in formol saline, save for a few blocks, some of which were kept in formol ammonium bromide for silver impregnation, and others fixed, together with blocks of liver and kidney, in absolute alcohol for glycogen staining. After prolonged fixation, the material was embedded in celloidin and in paraffin. Sections were stained with cresyl violet, $H$. and E., H.V.G., Best's carmine, P.T.A.H., P.A.S. and by the Heidenhain method for myelin and the Holzer method for glial cells and fibres. Frozen material was used for fat staining, for the Holzer method and for metal impregnation by the Bielschowsky, Gros-Bielschowsky, Cajal's gold sublimate and Hortega and Penfield's methods. Other stains were used as required.

The most conspicuous histological change was marked fibrous gliosis of the white matter. The Holzer and the silver impregnation preparations presented many single or paired large fibre-bearing astrocytes in all parts of the white matter (Fig. 2), the gliosis being accentuated around ventricles and the margin of the brain-stem. The myelin fibres showed diffuse pallor of staining in most areas and particularly in the white matter of the cerebral hemispheres. In addition, the white matter of the centrum semi-ovale, internal capsule, brain-stem and cerebellum contained many round 'punched-out' foci of 
total or partial dissolution of tissue, unaccompanied by any cellular reaction around them (Fig. 3). The cellular constituents of the lesions themselves were considerably or totally depleted. Many of these lesions were perivascular, but some bore no apparent relation to blood vessels. The above changes in the white matter, and chiefly the gliotic scarring, had resulted in a reduction of the volume of the centrum semi-ovale and its digital extensions, and accounted thereby for most of the micrencephaly and gyral sclerosis.

Nerve cells throughout the central nervous system showed some central chromatolysis and unevenness of staining. The cytoplasm of some of the larger cells contained a fine, powdery lipofuscin deposit-probably pathological in a child of 8 years.

Intracellular sudanophil particles were present in compound granular corpuscles arranged rather sparsely around a few of the blood vessels in the cerebral cortex and white matter. Finer sudanophil particles were also present in the endothelial cells of many capillaries. The plasma contained in many capillaries was sudanophil, possibly indicative of terminal lipaemia. The alcoholfixed material, when stained with P.A.S. or Best's carmine and controlled as required with diastase, showed no glycogen in neurons or any part of the grey matter. Very few minute glycogen granules were present in the white matter, chiefly around blood vessels, either in the 'empty' perivascular spaces or in the solid tissue adjoining these spaces.

The meninges were normal but for a localized collagenous thickening of the arachnoid membrane over the vertex of the brain. A slight excess of astrocytes and glial fibres was present in the molecular layer of the cerebral cortex. The cortical lamination was undisturbed and no laminar or focal neuronal loss could be detected, although a few of the neurones had lost almost all their staining affinity. (Mild and diffuse neuronal loss cannot be ascertained by usual neuropathological methods.) The pyramidal cell layer curving round the Sommer sector of the hippocampus was split in two parallel laminae (Fig. 4) separated by apparently normal neural tissue. The meaning of this anomaly is uncertain since the rest of the hippocampus was quite normal.

The putamen and caudate nuclei were normal, presenting in particular the usual numerical ratio of large to small cells. The globus pallidus showed some gliosis and a strikingly large accumulation of mainly extracellular, large sudanophil particles (Fig. 5). Nevertheless, there was no certain neuronal loss in that formation. The thalamus showed many small focal clusters of hyperplastic microglial cells and some neuronophagia. There was slight neuronal loss in the centromedian and the ventrolateral nuclei.

Some neuronophagia was present in the inferior colliculus and nucleus cuneiformis, and cellular and fibrous gliosis was marked in the inferior olives, which also showed focal neuronal loss.

The cerebellar Purkinje cells were severely depleted and there was marked proliferation of the Bergmann glia (Fig. 6). Many of the surviving Purkinje cells were chromatolytic and pyknotic; some were displaced peri-

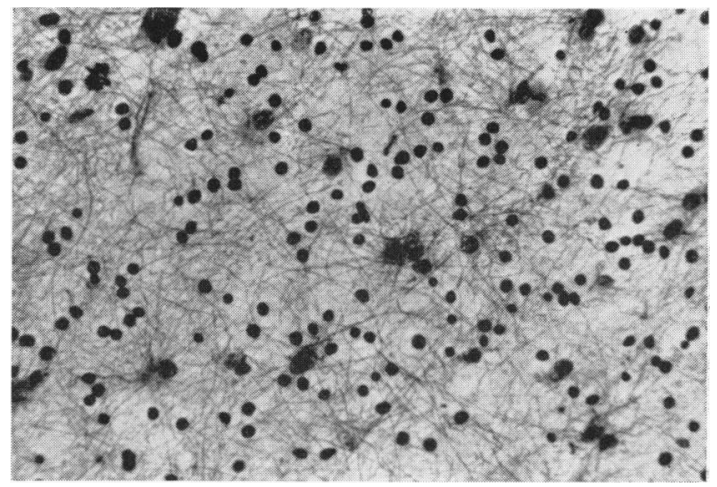

Fig. 2.-Fibrous gliosis of the white matter. (Holzer $\times 258$.)

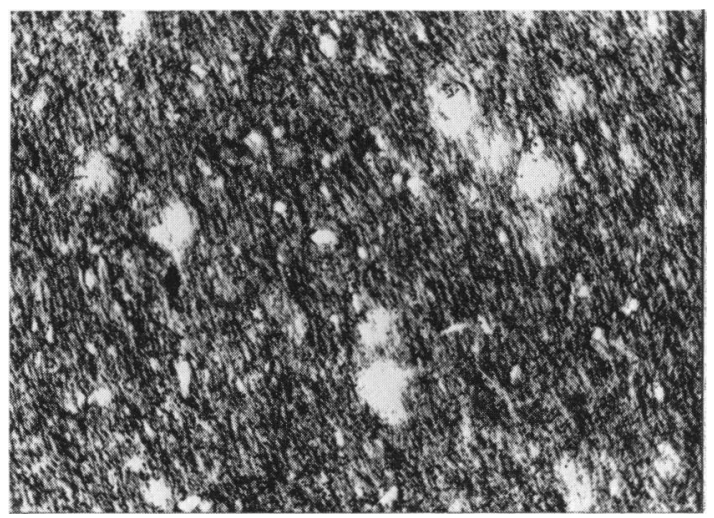

FIG. 3.--'Punched-out' necrotic areas in the white matter. (P.T.A.H. $\times$ 73.)

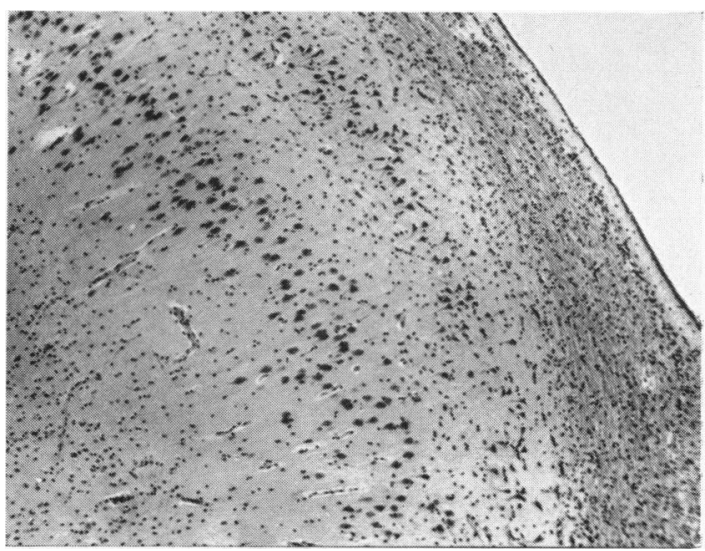

FIG. 4.-Double layer of pyramidal cells in the hippocampus. (H.V.G. $\times$ 44.) 


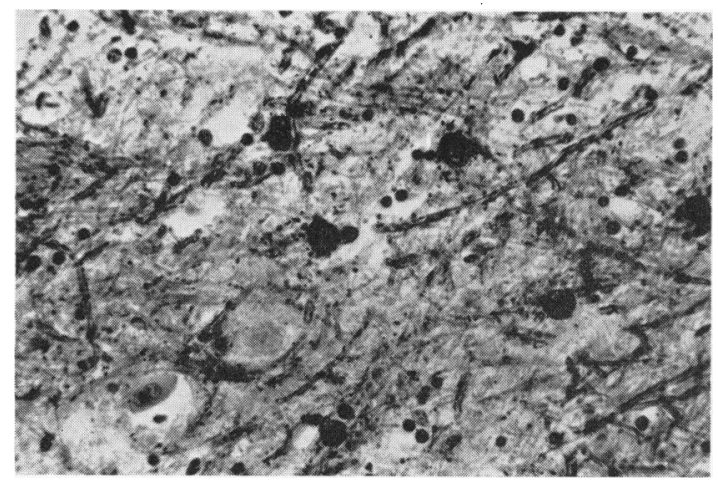

Fig. 5.-Extracellular globules of neutral fat in the globus pallidus. (Herxheimer $\times$ 258.)

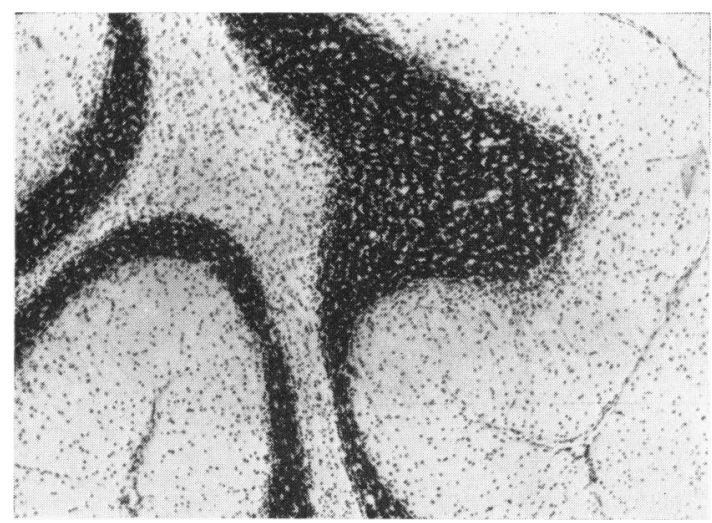

Fig. 6.-Loss of Purkinje cells and proliferation of Bergmann glia in the cerebellum. (Cresyl violet $\times 44$.)

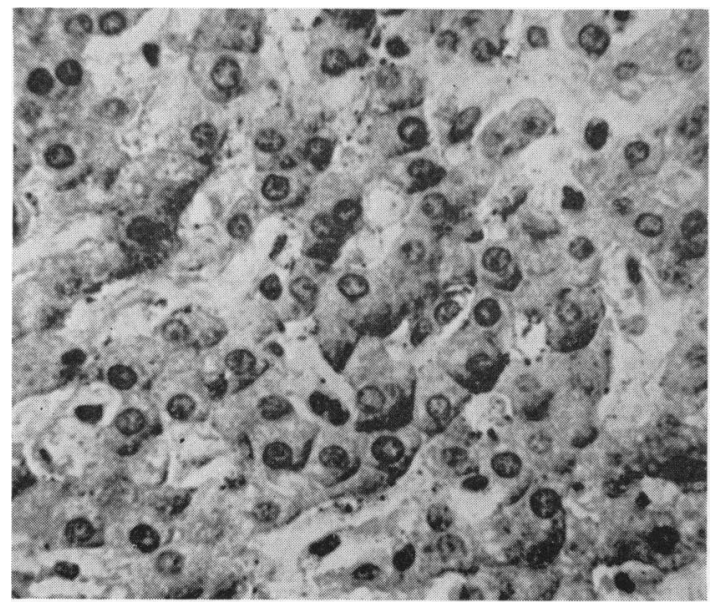

FIG. 9.-Glycogen deposit in hepatic cells showing 'streaming' or polarization. (Best's carmine $\times$ 236.)

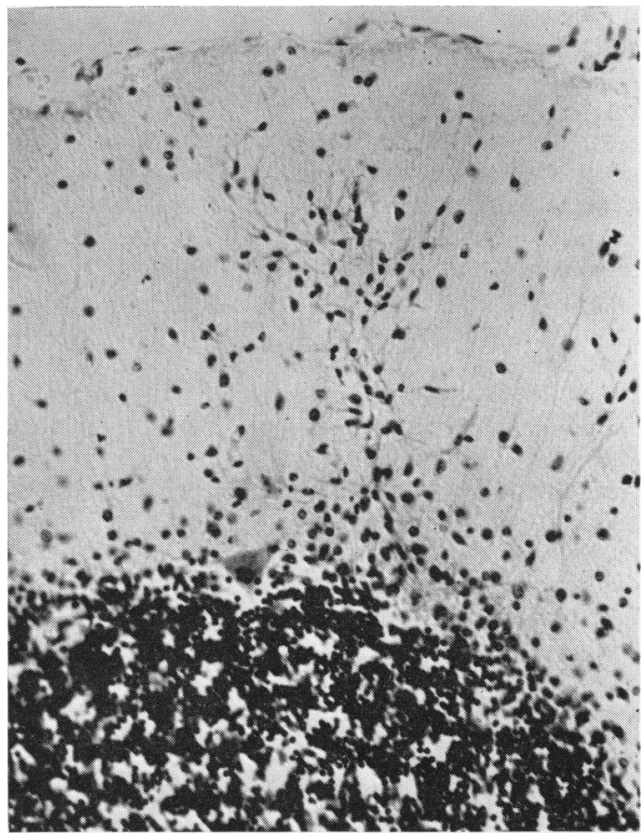

FIG. 7.--'Trellis-work' gliosis of the cerebellar molecular layer. $($ Cresyl violet $\times 178$.)

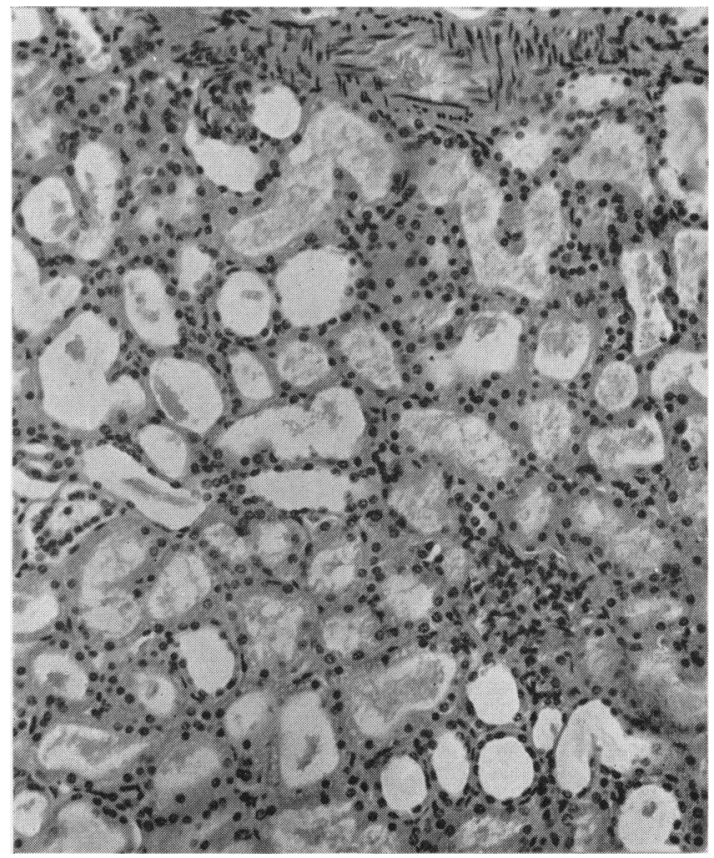

FIG. 8.-Dilatation of the proximal and distal convoluted tubules of the kidney with flattening of the epithelial cells. (H. and E. $\times$ 157.) 
TABLE 2

CHEMICAL EXAMINATION OF BRAIN, LIVER AND SPLEEN (g./100 g. DRY TISSUE) WITH FIGURES£FOR NORMAL OF SAME AGE IN PARENTHESIS

\begin{tabular}{|c|c|c|c|c|c|c|c|c|c|c|}
\hline & & & & & & & $\begin{array}{c}\text { Cerebral } \\
\text { White Matter }\end{array}$ & $\begin{array}{c}\text { Cerebral } \\
\text { Cortex }\end{array}$ & Liver & Spleen \\
\hline $\begin{array}{l}\text { Total phospholipid } \\
\text { Total cholesterol . } \\
\text { Esterified cholesterol } \\
\text { Cerebroside } \\
\text { Total hexosamine } \quad . \\
\text { Neuraminic acid } \quad .\end{array}$ & $\begin{array}{l}\cdots \\
\cdots \\
\cdots \\
\cdots \\
\cdots\end{array}$ & $\begin{array}{l}\cdots \\
\cdots \\
\cdots \\
\cdots\end{array}$ & $\begin{array}{l}\cdots \\
\cdots \\
\cdots \\
\cdots\end{array}$ & $\begin{array}{l}\cdots \\
\cdots \\
\cdots \\
\cdots\end{array}$ & $\begin{array}{l}\cdots \\
\cdots \\
\cdots \\
\cdots\end{array}$ & $\begin{array}{l}\cdots \\
\cdots \\
\cdots \\
\cdots \\
\cdots\end{array}$ & $\begin{array}{c}13 \cdot 1(23 \cdot 0) \\
10.9(15 \cdot 7) \\
0.4(0) \\
14 \cdot 5(17 \cdot 9) \\
0.4(0.23) \\
-\quad(0.07)\end{array}$ & $\begin{array}{cl}11 \cdot 0 & (19 \cdot 6) \\
5 \cdot 5 & (5 \cdot 5) \\
0.9 & (0) \\
7 \cdot 8 & (4 \cdot 1) \\
\overline{0.27} & (0 \cdot 6) \\
(0 \cdot 35)\end{array}$ & $\begin{array}{l}5 \cdot 0 \\
0 \cdot 5 \\
0 \cdot 07 \\
1 \cdot 32 \\
- \\
-\end{array}$ & $\begin{array}{l}3 \cdot 3 \\
2 \cdot 2 \\
0 \cdot 04 \\
1 \cdot 66 \\
- \\
-\end{array}$ \\
\hline Water $(\%) \ldots$ & .. & .. & .. & $\ldots$ & $\cdots$ & $\cdots$ & $72 \cdot 7(71 \cdot 3)$ & $79 \cdot 1 \quad(83 \cdot 7)$ & $69 \cdot 7$ & $75 \cdot 2$ \\
\hline
\end{tabular}

pherally into the molecular layer. The latter was narrowed in certain areas, showing fibrous gliosis and, also, fresh foci of 'trellis-work' glial proliferation (Fig. 7). The granular layer was, in the main, spared, showing some neuronal loss in only a few of the folia. Some neuronal loss was present in the dentate nucleus where many of the surviving cells were distended, vacuolated and chromatolytic.

The spinal cord showed no measurable neuronal loss, but marked fibrous gliosis was present in the grey matter, especially around its periphery and in the white matter.

Somatic Organs. The body at autopsy was dehydrated and weighed $12 \cdot 25 \mathrm{~kg}$. The lungs (left, $190 \mathrm{~g}$.; right, 289 g.) showed confluent bronchopneumonia. The heart (76 g.) was normal. The kidneys (left, 64 g.; right, $68 \mathrm{~g}$.) showed slight dilatation of many of the proximal and distal convoluted tubules with flattening of their cells (Fig. 8). A few of the collecting tubules contained granular casts. Glycogen could be demonstrated in many epithelial cells of the convoluted tubules, loops of Henle and in a few of the glomerular epithelial tufts. The liver $(585 \mathrm{~g}$.) showed diffuse fatty change and siderosis of both parenchymatous and Kupffer cells. Portal tracts were mildly infiltrated by lymphocytes. A considerable amount of glycogen was present in many parenchymatous and a few of the Kupffer cells. It was distributed diffusely throughout the cytoplasm and nuclei of some cells. In others, it was concentrated peripherally in the form of rows or crescents parallel with the deposit in neighbouring cells (Fig. 9). This phenomenon of 'streaming' or polarization is believed to be an artefact produced by the rapidly penetrating fixative carrying the glycogen to the innermost end of each cell (Manns, 1958). Some glycogen granules lay free in the Disse's spaces. Many areas of the liver were, however, entirely free from glycogen. The spleen (26 g.) presented marked siderosis. The pituitary $(0.25 \mathrm{~g}$.), thyroid (3.6 g.) and adrenals (left, $4.7 \mathrm{~g}$.; right, $4.4 \mathrm{~g}$.) were histologically normal. The testes presented much interstitial fibrosis and tubular atrophy. The parathyroids were formed only by 'chief' cells. The pancreas, thymus, pineal gland and salivary glands were all normal.

Chemical Findings. The chemical examination of the brain, liver and spleen (Prof. J. N. Cumings) is given in
Table 2. Figures for normals of the same age are taken from Szliwowski and Cumings (1961).

There was thus some loss of phospholipid in both the white matter and cortex, with slightly more cholesterol ester in the cortex than normal.

The urine collected at autopsy was examined as part of a wider survey. It contained $400 \mathrm{mg} . / 100 \mathrm{ml}$. of sucrose and a trace of glucose.

\section{Discussion}

The above neural changes may be summarized as micrencephaly caused by a mainly burnt-out gliotic encephalomyelopathy. Certain minor features such as the 'trellis-work' microglial gliosis of the cerebellar molecular layer indicate a slowly continuous or intermittent process, and others are probably terminal. The significance of the 'punched-out' necrotic lesions in the white matter is somewhat obscure. They have been described in a number of conditions, such as renal disease (Bodechtel and Erbslöh, 1958) and have also been observed in fatal cases of cardiac arrest and hypothermia (J. B. Brierley, personal communication). All the findings are, on the whole, unspecific and can be encountered in the brains of mentally retarded individuals of different types. Some occur, for example, in phenylketonuria (Crome and Pare, 1960). In such cases, the evidence suggests early postnatal onset of the encephalopathy, but late prenatal origin cannot be entirely excluded.

It is well known that established mental retardation tends to remain refractory in cases of galactosaemia, even after the withdrawal of galactose from the diet, in spite of the reversibility of other signs, e.g. cataracts, hepatic cirrhosis, enteritis and jaundice. This persistence of mental retardation is understandable in the light of the structural neural changes in the present case. However, in the absence of other neuropathological studies it is uncertain how representative the case is of galactosaemia as a whole. The bilirubinaemia of $26 \mathrm{mg}$./ $100 \mathrm{ml}$. certainly appears high compared with other recorded cases. Moreover, the patient has never 
been on a completely galactose-free diet: 'Casilan' is known to contain about $1 \%$ of lactose, and some of this hexose is also present in butter fat. Similarly, treatment may not have been entirely adequate in the previously reported cases with persistent mental retardation.

While the precise neuropathological features have not been known, it has been usual to incriminate either hypoglycaemia or some form of competitive inhibition as the cause of the encephalopathy. Neonatal jaundice should, perhaps, be also considered in this context.

Hypoglycaemia no longer finds favour with most workers as the sole or chief cause of the encephalopathy (Komrower, Schwarz, Holzel and Golberg, 1956; Wright, Tarjan, Lippman and Perry, 1958; Kalckar, 1959; Isselbacher, 1960; Kirkman, 1960). It is held that hypoglycaemia seldom reaches dangerously low levels in galactosaemia and that, in conditions such as glycogen storage disease where blood sugar frequently falls to levels lower than in galactosaemia, mental retardation is unusual. Unfortunately, little is known of the neuropathological findings in hypoglycaemic infants and children. In adults, the lesions fall most heavily on the cerebral cortex, the caudate nucleus, the putamen, the cerebellum and the hippocampus. The white matter may also be secondarily involved. Since the history of the present case excludes frequent, prolonged or severe hypoglycaemia while the pathological findings are quite unlike those in hypoglycaemic adults, this factor may, perhaps, be discounted as the cause of the encephalopathy.

Neonatal jaundice may leave behind it permanent encephalopathy and, since severe jaundice is one of the most constant of the early signs in galactosaemia, its possible harmful effect cannot easily be dismissed. It is true that the clinical course of galactosaemia does not run close to that of typical residual kernikterus with its marked motor dysfunction, but the sequelae of kernikterus are by no means uniform (Crome, Kirman and Marrs, 1955). The neural lesions in residual kernikterus are situated chiefly, but not exclusively, in the basal ganglia, particularly the globus pallidus and subthalamic nucleus. There is thus little morphological similarity with the present case if one excepts the globus pallidus. The changes in that formation are certainly similar in both conditions (Crome, 1955). It may hence be unwise to exclude severe neonatal jaundice as a contributory cause of the encephalopathy. It is possibly significant that the few recorded cases of galactosaemia without neonatal jaundice have tended to be more intelligent than the rest, as for example Cases 2 and 4 of
Townsend, Mason and Strong (1951), each with an I.Q. of 85. Since it is thought that permanent neural damage can only be caused by unconjugated bilirubin, it would be of obvious interest to establish the ratio of unconjugated to conjugated bilirubin in severely jaundiced galactosaemic infants. Recorded studies throw no light on this problem.

As matters stand, some competitive inhibition will probably prove to be the chief factor responsible for the neuropathy. It has been demonstrated, for example, that galactose-1-phosphate, which is known to be present in many tissues of galactosaemic patients, can inhibit such enzymes as phosphoglucomutase and glucose 6-phosphate dehydrogenase (Holzel, 1961). Future studies will no doubt establish whether this or some similar mechanism accounts fully for galactosaemic encephalopathy.

The unexpected presence of sucrose in the terminally excreted urine of the present case calls for explanation. It has been tentatively suggested by Moncrieff and Wilkinson (1954) that the combination of sucrosuria, hiatus hernia and mental retardation may constitute a metabolic disease sui generis. Subsequent experience did not bear this out. The sucrosuria of terminal illnesses in mental defectives is probably an incidental event related to the type of diet and altered absorption by the intestinal tract during these illnesses (Stern and Sylvester, 1962).

Cataracts apart, the only somatic structural changes previously described in galactosaemia are in the liver. This usually shows marked fatty degeneration or changes resembling Laennec's cirrhosis (Donnell and Lann, 1951; Townsend et al., 1951). It is known that the onset of cirrhosis can be averted or even reversed by withdrawing galactose from the diet (Pugh, 1953). The occurrence of hepatic adenomata consisting of glycogen-containing cells without excess of glycogen in other parts of the liver has been reported by Edmonds, Hennigar and Crooks (1952). Hepatic adenomata were absent in the present case, but the liver and kidneys showed substantial glycogen deposition and a minimal amount of the substance was present in the white matter of the brain. None was demonstrable in other organs, but these were fixed only in aqueous formalin and some glycogen may have easily diffused out of the tissue. Siderosis was present in the liver and spleen, caused by iron administration. The significance of renal tubular dilatation is uncertain, but may be related to the terminal sucrosuria.

\section{Summary}

A galactosaemic infant, with severe jaundice, hepatomegaly and lenticular opacities appearing at 
3 weeks, recovered after the withdrawal of most lactose from the diet. The lenses cleared and remained clear. Mental retardation was, however, persistent. The child died at 8 years and the main neuropathological findings consisted of slight micrencephaly with pronounced fibrous gliosis of the white matter. The cerebellum showed marked loss of Purkinje cells and less conspicuous loss of the granular layer. Most of the larger nerve cells throughout the central nervous system contained slight excess of cytoplasmic lipofuscin. The only noteworthy somatic changes were slight dilatation of the renal convoluted tubules or loops of Henle, and glycogenosis of the liver and kidney.

Many colleagues in several hospitals have investigated different aspects of this case, and I am grateful to all of them for their records. My thanks are also due to Professor J. N. Cumings for the neurochemical analysis of the brain. Dr. A. Holzel has kindly commented on the manuscript, and I have incorporated his observations in the text. Dr. V. Schwarz and my colleagues at the Fountain Hospital have likewise helped greatly by reading and criticizing this report.

\section{REFERENCES}

Bodechtel, G. and Erbslöh, F. (1958). Die Veränderungen des Zentralnervensystems bei Nierenkrankheiten. In Handbuch der speziellen pathologischen Anatomie und Histologie, ed $\mathrm{O}$. Lubarsch, F. Henke and R. Rössle, Vol. 13, Part II, B., p. 1397. Springer, Berlin.

Clay, P. R. and Potter, C. T. (1955). A case of galactosaemia with special reference to mental development. Arch. Dis. Childh. 30, 147 .
Crome, L. (1955). Morphological nervous changes in survivors of severe jaundice of the newborn. J. Neurol. Neurosurg. Psychiat., $18,17$.

Kirman, B. H. and Marrs, M. (1955). Rhesus incompatibility and mental deficiency. Brain, 78, 514.

- and Pare, C. M. B. (1960). Phenylketonuria: a review and a report of the pathological findings in four cases. J. ment. Sci., 106, 862.

Cusworth, D. C., Dent, C. E. and Flynn, F. V. (1955). The aminoaciduria in galactosaemia. Arch. Dis. Childh., 30, 150.

Donnell, G. N. and Lann, S. H. (1951). Galactosemia. Report of four cases. Pediatrics, $7,503$.

Edmonds, A. M., Hennigar, G. R. and Crooks, R. (1952). Galactosemia; report of case with autopsy. ibid., 10, 40 .

Holzel, A. (1961). Galactosaemia. Brit. med. Bull., 17, 213.

Isselbacher, K. J. (1960). Galactosemia. In The Metabolic Basis of Inherited Disease, ed. J. B. Stanbury, J. B. Wyngaarden of Inherited Disease, ed. J. B. Stanbury, J. B. Wyngaard

Kalckar, H. M. (1959). Biochemical genetics as illustrated by hereditary galactosaemia. In Ciba Foundation Symposium on Biochemistry of Human Genetics, ed. G. E. W. Wolstenholme and C. M. O'Connor, p. 23. Churchill, London.

Kirkman, H. N. (1960). Galactosemia. Metabolism, 9, 316

Komrower, G. M., Schwarz, V., Holzel, A. and Golberg, L. (1956). A clinical and biochemical study of galactosaemia. A possible explanation of the nature of the biochemical lesion. Arch. Dis. explanation of the

Manns, E. (1958). The preservation and demonstration of glycogen in tissue sections. J. med. Lab. Technol., 15, 1 .

Moncrieff, A. and Wilkinson, R. H. (1954). Sucrosuria with mental defect and hiatus hernia. Acta paediat. (Uppsala), 43, Suppl. 100, p. 495 .

Pugh, R. J. (1953). Liver drainage and congenital galactosaemia. Arch. Dis. Childh., 28, 245.

Stern, J. and Sylvester, P. E. (1962). Sucrosuria, hiatus hernia and mental retardation. In Proceedings of the London Conference on the Scientific Study of Mental Deficiency, Vol. I, p. 153. May and Baker, Dagenham.

Szliwowski, H. B. and Cumings, J. N. (1961). Les Lipides cérébraux dans l'encéphale subaiguë. Acta neurol. belg., 61, 153.

Townsend, E. H. Mason, H. H. and Strong, P. S. (1951). Galactosemia and its relation to Laennec's cirrhosis. Review of the literature and presentation of six additional cases. Pediatrics, 7, 760 .

Wright, S. W., Tarjan, G., Lippman, R. W. and Perry, T. L. (1958) Etiologic factors in mental deficiency. Errors of metabolism that may lead to mental deficiency. A.M.A. J. Dis. Child. 95,541 . 